\title{
Print, Sign, Date Form
}

National Cancer Institute

\section{Source}

National Cancer Institute. Print, Sign, Date Form. NCI Thesaurus. Code C157107.

A directive to print the form, sign and date the section indicated. 